\title{
Performance and Egg Quality of Laying Hens Fed Ration Containing Coriander Seeds (Coriandrum sativum Linn)
}

\author{
U. Habiyaha, R. Mutia ${ }^{b^{*}}, \&$ S. Suharti ${ }^{\mathrm{b}}$ \\ aStudy Program of Nutrition and Feed Science, Faculty of Animal Science, Graduate School, \\ Bogor Agricultural University \\ ${ }^{b}$ Department of Nutrition and Feed Technology, Faculty of Animal Science, Bogor Agricultural University \\ Jalan Agatis, Kampus IPB Darmaga Bogor 16680, Indonesia \\ (Received 21-08-2015; Reviewed 15-09-2015; Accepted 15-02-2016)
}

\begin{abstract}
The aims of this study were to determine the effect of diets containing different levels of coriander seeds on performance and egg quality of Lohmann Brown laying hens. A total of 96 Lohmann Brown laying hens of 43 weeks of age were randomly allocated into 16 experimental units by assigning a completely randomized design with 4 treatments and 4 replications that kept for 6 weeks. The treatment diets were R0: diet with $0 \%$ supplementation of coriander seeds powder (control), R1: diet with supplementation of $1 \%$ coriander seeds powder, R2: diet with supplementation of $2 \%$ coriander seeds powder, and R3: diet with supplementation of $3 \%$ coriander seeds powder. The results showed that supplementation of coriander seeds in diets did not affect egg weight, egg production, and egg mass. Supplementation of coriander seeds $2 \%-3 \%$ significantly $(P<0.05)$ decreased feed consumption and feed conversion ratio. Supplementation of coriander seeds $1 \%-3 \%$ significantly $(\mathrm{P}<0.05)$ increased yellowness in yolk color without affecting other quality parameters. It can be concluded that supplementation of coriander seeds at the levels of $2 \%-3 \%$ decreased feed intake, feed conversion ratio, and increased yolk color, however, the supplementation at all levels in diets did not affect egg weight, egg production, and egg mass.
\end{abstract}

Key words: coriander seeds, egg quality, laying hens, performance

\section{ABSTRAK}

Penelitian ini bertujuan untuk mengkaji penampilan produksi dan kualitas telur ayam petelur Lohmann Brown yang disuplementasi biji ketumbar yang mengandung minyak atsiri dengan level berbeda dalam ransum. Sebanyak 96 ekor ayam petelur Lohmann Brown berumur 43 minggu digunakan dalam penelitian ini. Penelitian ini menggunakan rancangan acak lengkap dengan empat perlakuan dan empat ulangan. Pakan percobaan ditambahkan tepung ketumbar $0 \%$ (kontrol), $1 \%$, $2 \%$, dan 3\% selama 6 minggu. Hasil penelitian menunjukkan bahwa suplementasi biji ketumbar dalam ransum tidak berpengaruh pada bobot telur, produksi telur, dan massa telur. Sementara suplementasi biji ketumbar $2 \%-3 \%$ nyata $(P<0,05)$ menurunkan konsumsi pakan dan rasio konversi pakan. Suplementasi biji ketumbar $1 \%-3 \%$ nyata $(\mathrm{P}<0,05)$ meningkatkan warna kuning telur tanpa mempengaruhi parameter kualitas lainnya. Dapat disimpulkan bahwa suplementasi biji ketumbar $2 \%-3 \%$ dalam pakan dapat menurunkan konsumsi pakan, rasio konversi pakan dan meningkatkan warna kuning telur, namun demikian suplementasi tidak berpengaruh pada bobot, produksi, dan massa telur.

Kata kunci: ayam petelur, ketumbar, kualitas telur, performa produksi

\section{INTRODUCTION}

Laying hens is a potential poultry to be developed in Indonesia because the demand of egg continues to rise every year. Public awareness of organic food has

*Corresponding author:

E-mail: rmutia.1@gmail.com increased along with the discovery of a wide range of adverse side effects of using chemicals in food products. The development of population of laying hens in Indonesia in 2013 by the Directorate General of Livestock amounted to 146.622 .000 , while the number of eggs produced amounted to 1.224.402 tons. In 2014 population and livestock production in Indonesia was 154.657.000 and 1.299.199 tons, respectively (BPS 2015). 
Recently, the search for non-synthetic feed as alternatives for antibiotics has been found. Phytogenic feed additives such as herbs and spices have been supplemented into the diets of livestock and poultry to improve flavor and palatability, therefore enhancing production performance (Windisch et al., 2008). A wide range of herbal plants contain bioactive compounds which have the potential as feed supplements for animals. Coriander seed (Coriandrum sativum Linn) is aromatic plant which is used as a flavoring agent in the food industry and has a long history as a traditional medicine containing an essential oil up to $1 \%$. The main component of essential oil found in coriander seed is linalool, which has potential as antibacterial (Silva, 2011; Matasyoh et al., 2008), insecticidal (Khani \& Tahere Rahdari, 2012), nematicidal (Kim et al., 2008), antibiotic (Hosseinzadeh et al., 2014), and antimicrobial (Begnami et al., 2010; Burdock \& Carabin, 2008). It also has appetize effect and ezyme activity in the digestion process (Rajeshwari \& Andallu, 2011). Coriander is also well known for antioxidant, anti-diabetic, anti-mutagenic, and improving enzyme activity and hormone balancing so increase the health of livestock (Bhat et al., 2014).

Essential oils are secondary metabolites that are abundant in aromatic plants families such as Lamiaceae and Apiaceae which contain a large number of compounds such as monoterpenes and sesquiterpenes (Rajeshwari \& Andallu, 2011). Aromatic plants contain a variety of functional bioactive compounds. Viable alternative methods for enhancing performance or improving shelf-life of the animal products may be developed, satisfying the consumer's demands for natural, safe, and high quality foods (Christaki et al., 2012). The major compounds present in essential oil are linalool $(67.70 \%)$; $\alpha$-pinene $(10.5 \%) ; \gamma$-terpinene $(9.0 \%)$; geranyl acetate (4.0\%); camphor (3.0\%); and geraniol (1.9\%) (Khani \& Rahdari, 2012).

The effects of herbal plant on chicken performance have been get much attention. Herbs and spices are potential antimicrobial agents that can be used against various pathogens and as alternative natural antibacterial to replace antibiotic (Lee et al., 2013). According to Abou-Elkhair et al. (2014) suplementation of black pepper and coriander seeds or their combinations in feed enhance the performance and health status of broiler chickens. Brenes \& Roura (2010) suggest that the use of herbal plants need to be checked because there are certain interactions on the number and variability of bioactive compounds. Therefore, the aim of the current study was to evaluate the effects of supplementary coriander seeds on production performance, egg production and egg quality of laying hens.

\section{MATERIALS AND METHODS}

\section{Animals, Diets, and Feeding Treatment}

A total 96 of Lohmann brown laying hens of 43 weeks of age with average body weight of $1.670 \pm 0.11 \mathrm{~g}$ were kept in individual cages of $35 \times 40 \times 45 \mathrm{~cm}$ in size for 6 weeks. Feed ingredients were obtained from PT. Indofeed Bogor. The laying hens were distributed into a completely randomized design with 4 treatments and 4 replications (6 birds each).

The contents of coriander seeds powder were dry matter $91.79 \%$, ash $5.33 \%$, crude protein $13.03 \%$, crude fat $20.33 \%$, and crude fiber $30.39 \%$ that were measured by using method of AOAC (2005). The content of atsiri oil in the coriander seeds was $0.63 \%$ (Balitro, 2015). Experimental diets were formulated with the same levels of protein (18.12\%) and metabolizable energy $(2875.34 \mathrm{kcal} / \mathrm{kg})$ according to recommendation of Leeson \& Summers (2005) (Table 1). The diet treatments were R0: supplementation of $0 \%$ coriander seeds powder (control), R1: supplementation of $1 \%$ coriander seeds powder, R2: supplementation of $2 \%$ coriander seeds powder, and R3: supplementation of $3 \%$ coriander seeds powder (Table 1). Feed and drinking water were provided ad libitum.

\section{Recording Performance and Egg Quality}

Egg production and egg weight were recorded daily. Feed consumption and feed conversion ratio were recorded weekly. Egg quality analysis was performed weekly by using 32 eggs from each group. Yolk color was determined by using a Roche color fan (1 to 15). Egg quality parameters were calculated by the following formulas (Stadelman \& Cotterill, 1995):

Yolk ratio $=$ [yolk weight $(\mathrm{g}) / \mathrm{egg}$ weight $(\mathrm{g})] \times 100$ Albumen ratio $=[$ albumen weight $(\mathrm{g}) / \mathrm{egg}$ weight $(\mathrm{g})] \mathrm{x}$ 100

Shell ratio $=[$ shell weight $(\mathrm{g}) / \mathrm{egg}$ weight $(\mathrm{g})] \times 100$

Table 1. Composition and nutrient contents of the treatment $\operatorname{diet}$ (as fed)

\begin{tabular}{lr}
\hline Composition & Total \\
\hline Feed ingredients (\%) & \\
Yellow corn & 51.00 \\
Corn gluten meal & 4.50 \\
Soybean meal & 23.67 \\
Fish meal & 8.00 \\
Palm oil & 2.50 \\
DCP & 0.40 \\
CaCO & 9.20 \\
NaCl & 0.20 \\
Premix & 0.50 \\
DL-Methionine & 0.03 \\
Total & 100.00 \\
Nutrient content $\left.{ }^{*}\right)$ & \\
Metabolizable energy (kcal/kg) & 2875.34 \\
Crude protein $(\%)$ & 18.12 \\
Crude fiber (\%) & 2.18 \\
Ether extract (\%) & 4.58 \\
Ca (\%) & 4.16 \\
P available (\%) & 0.52 \\
Lysine (\%) & 1.33 \\
Methionine (\%) & 0.52 \\
Methionine + Lysine (\%) & 0.89 \\
\hline
\end{tabular}

Note: *Nutrients content of ingredients according to Leeson \& Summers (2005). 
Haugh unit: $100 \log \left(\mathrm{H}+7.57-1.7 \mathrm{~W}^{0.37}\right), \mathrm{H}$ : albumin height (mm), W: egg weight (g).

\section{Statistical Analysis}

Data obtained were analyzed by analysis of variance (ANOVA). If there was a significant different among traetments, the data were further analysed by using Duncan's multiple range test (Mattjik \& Sumertajaya, 2006).

\section{RESULTS AND DISCUSSION}

\section{Laying Hens Performance}

Supplementation of coriander seeds at all levels in the diet did not affect the egg weight (Table 2). This weight was not different from that reported by Bidura et al. (2014) that egg weight of Lohmann brown at the age of 42-50 weeks was $58.12 \mathrm{~g}$. Factors affecting egg weight are protein consumption (Tuleun \& Adenkola, 2013) and age (Tserveni-Goussi \& Fortomaris, 2011). According to Leeson \& Summers (2005), protein and amino acids (especially methionine) are nutrients that have important roles in controlling of eggs size.

Supplementation of coriander seeds powder $2 \%-3 \%$ in the ration significantly decreased feed intake $(\mathrm{P}<0.05)$ (R2 and R3) as compared with control (R0) (Table 2). There was no significant different in feed intake among coriander seeds treatments. This result implied that coriander seeds in the diet stimulated digestive organ so digestion proses will be optimal. The effectivity of essential oils in the digestive system can be seen from the production of eggs. Guler et al. (2005) reported that coriander seeds could be considered as a potential natural growth promoter for poultry, and showed the best responses at a $2 \%$ level of inclusion. The essential oils contained in coriander seeds were about $0.5 \%-1 \%$, and these levels had antimicrobial or antibacterial effects. Silva et al. (2011) reported that atsiri oil had antibacteria activity. Abou-Elkhair et al. (2014) said that supplementation of feed with black pepper and coriander, or a combination of both, could improve the performance and health status of broilers and can be used as a dietary supplement as a natural growth promotor.
Supplementation of coriander seeds did not affect egg production. According to Leeson \& Summers (2005), egg production is affected by the strain, age, feed consumption, water consumption, the consumption of mineral, and protein content of feed. Al-Jaff (2011) reported that the addition of coriander $2 \%-3 \%$ in broiler chicken rations had positive effects on the blood profile, performance, and immune system at high temperatures. Coriander seeds contain an essential oil up to $1 \%$, the main component is linalool, which has potentials as antibacterial (Silva, 2011; Matasyoh et al., 2008) and, antioxidant (Bhat et al., 2014), which improve health condition and promote nutrient digestibility. In the present study, supplementation of coriander seeds at the level of $1 \%-3 \%$ in feed did not affect egg production. Coriander seeds containing atsiri oil has not been able to increase the production performance of laying hens.

Table 2 showed that the addition of $2 \%-3 \%$ coriander seed in the ration significantly $(\mathrm{P}<0.05)$ improved feed conversion ratio as compared to the control diet (R0). Feed conversion ratio indicated that chickens supplemented with coriander seed were more efficient in utilizing nutrients so that eggs production tended to be higher when compared to control (R0) (Figure 1). This lower feed conversion ratio was due to the lower feed consumption with the higher weight of the eggs produced. The average feed conversion ratio in this study was not different from that reported by Ahammed et al. (2014) said that feed conversion Lohmann brown age of 41-60 weeks was 2.21, but lower than that reported by Bidura et al. (2014) that feed conversion of Lohmann brown (42-50 of age weeks) was 3.01. According to Leeson \& Summers (2005), feed conversion ratio was affected by egg production, nutrient content of feed, egg weight, and temperature.

\section{Physical Quality of Egg}

The treatments did not significantly affect haugh unit value (Table 3). Results showed that the egg produced in this experiment were included in grade AA. Egg with haugh unit values $>72,60-72,31<60$, and $<31$ are categorized as AA, A, B, and C qualities, respectively (Stadelman \& Cotterill, 1995). Haugh unit value is obtained from the relationship between height of albumen

Tabel 2. Production performances and feed conversion ratio of laying hens fed diets containing different levels of coriander seeds powder

\begin{tabular}{lrrrr}
\hline \multirow{2}{*}{ Variables } & \multicolumn{5}{c}{ Treatments } \\
\cline { 2 - 5 } & \multicolumn{1}{c}{ R0 } & \multicolumn{1}{c}{ R1 } & R2 \\
\hline Egg weight (g) & $57.56 \pm 1.32$ & $58.11 \pm 0.38$ & $57.70 \pm 1.04$ & $57.30 \pm 1.69$ \\
Egg production (\%) & $76.69 \pm 1.99$ & $76.14 \pm 2.75$ & $80.06 \pm 2.62$ & $80.46 \pm 3.56$ \\
Egg mass (g/bird) & $1827.72 \pm 41.80$ & $1825.24 \pm 62.88$ & $1917.37 \pm 49.87$ & $1905.88 \pm 69.83$ \\
Feed intake (g/bird/d) & $104.44 \pm 1.07^{\mathrm{a}}$ & $102.66 \pm 0.09^{\mathrm{ab}}$ & $102.33 \pm 1.43^{\mathrm{b}}$ & $101.17 \pm 1.54^{\mathrm{b}}$ \\
Feed conversion ratio & $2.40 \pm 0.07^{\mathrm{a}}$ & $2.36 \pm 0.07^{\mathrm{a}}$ & $2.24 \pm 0.07^{\mathrm{b}}$ & $2.23 \pm 0.09^{\mathrm{b}}$ \\
\hline
\end{tabular}

Note: $\mathrm{R} 0=$ diet without supplementation $(0 \%)$ coriander seeds powder, $\mathrm{R} 1=$ diet with supplementation of $1 \%$ coriander seeds powder, $\mathrm{R} 2=$ diet with supplementation of $2 \%$ coriander seeds powder, R3= diet with supplementation of $3 \%$ coriander seeds powder. Means in the same row with different superscripts differ significantly $(\mathrm{P}<0.05)$. 


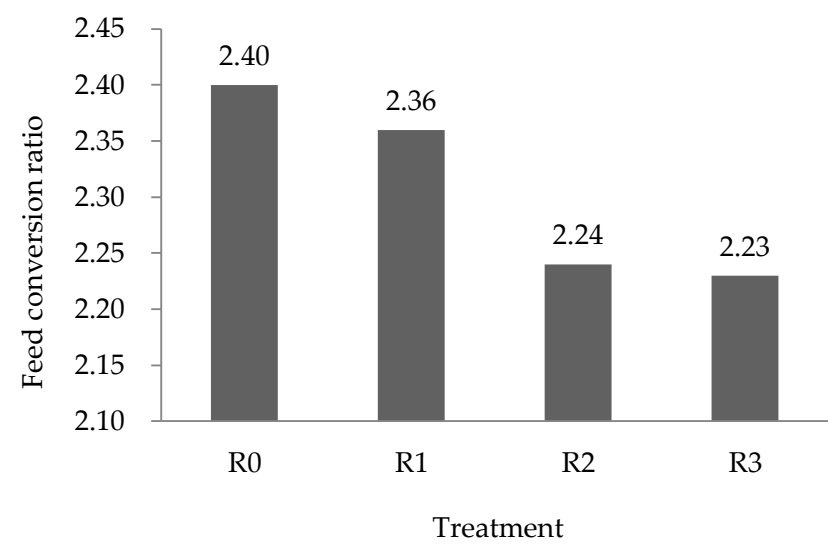

Figure 1. Average of feed conversion ratio of Lohmann Brown laying hens fed experimental diet, $\mathrm{R} 0=$ diet without supplementation $0 \%$ of coriander seeds powder (control), R1= diet with supplementation of $1 \%$ coriander seeds powder, $\mathrm{R} 2=$ diet with supplementation of $2 \%$ coriander seeds powder, $\mathrm{R} 3=$ diet with supplementation of $3 \%$ coriander seeds powder.

and egg weight. The average of haugh unit in this study was not much different from that reported by Olobatoke \& Mulugeta (2015) who reported that haugh unit of laying hens supplemented with garlic powder was 95.90, Mahmoud et al. (2010) reported that haugh unit of laying hens supplemented with garlic juice was 75.41, and Park et al. (2015) reported that haugh unit of laying hens (43 of age weeks) was 91.40. According to Nugraha et al. (2013), the absorption increased of amino acids could sustain ovomucin and lecithin thus enhancing the quality of eggs. Amino acids are used to raise the viscosity of albumen and haugh unit will increase. Furthermore, Honkatukia et al. (2013) explained that ovomucin was able to control the quality of the protein albumen and assist the process of egg albumen viscosity. The content of ovomucin in the egg albumen affects the value of haugh unit, the higher the egg albumen the higher the haugh unit values (Nugraha et al., 2013). Haugh unit values are greatly influenced by storage time and temperature of the environment.
There was no significant difference for albumens weight among treatments (Table 3). Supplementation of coriander seed did not affect albumen weight. The egg weight in this study was not different. Albumen weight is generally influenced by egg weight (Rajkumar et al., 2009). The averages of albumens weights in this research were lower than those reported by Cayan \& Erener (2015) that albumen weight was $38.70 \mathrm{~g}(64.60 \%)$ and Mahmoud et al. (2010) that albumen weight was $38.91 \mathrm{~g}$.

The treatments did not affect yolk weight. The averages of yolk weights in this research was not different from that reported by Cayan \& Erener (2015), the yolk weight was $14.60 \mathrm{~g}(24.30 \%)$, while lower than reported by Han \& Thacker (2011) and Mahmoud et al. (2010) that was $15.10 \mathrm{~g}$ and $16.34 \mathrm{~g}$, respectively. As proposed by Rajkumar et al. (2009) that egg size is more related to the size of the yolk compared with albumen, despite the fact that the albumen is still important factor that affect the size of an egg. It was reported that decreased yolk cholesterol levels could decrease yolk weight (Subekti et al., 2006)

Supplementation of coriander seeds by $1 \%-3 \%$ significantly $(\mathrm{P}<0.05)$ increased yolk color score. Meanwhile, yolk color score of treatment without supplementation of coriander seeds powder was 9 . Yolk color score in this research was not different from that reported by Cayan \& Erener (2015); Christaki et al. (2011); and Zangeneh \& Torki (2011) who said that the supplementation of olive leaf powder at $2 \%-3 \%$ in diet increased yolk color score. According to Loetscher et al. (2013), color is an important quality trait of foods since it affects the consumers' perception of quality and intensity of aroma and flavor. Supplementation of coriander seeds into the feed was able to increase the absorption of beta-carotene contained in the feed. According to Ahmad et al. (2012), the piperine powder was able to increase absorption of beta-carotene (a carotenoid) and other nutrients within the body. Hermana et al. (2014) reported that the carotenoid supported the high yolk color score since it had the same function with xanthophylls. Furthermore, Hammershoj et al. (2010) that the yolk color score was influenced by the consumption of

Tabel 3. The egg quality of laying hens fed diets containing different levels coriander seeds powder

\begin{tabular}{|c|c|c|c|c|}
\hline \multirow{2}{*}{ Variables } & \multicolumn{4}{|c|}{ Treatments } \\
\hline & R0 & R1 & $\mathrm{R} 2$ & R3 \\
\hline Haugh unit & $97.75 \pm 0.52$ & $96.74 \pm 1.07$ & $97.40 \pm 0.42$ & $97.10 \pm 0.52$ \\
\hline Albumen weight (g) & $37.82 \pm 1.97$ & $37.38 \pm 1.22$ & $36.83 \pm 1.61$ & $37.39 \pm 0.88$ \\
\hline Albumen weight (\%) & $63.98 \pm 2.11$ & $63.27 \pm 0.81$ & $62.75 \pm 0.83$ & $63.07 \pm 0.43$ \\
\hline Yolk weight (g) & $13.95 \pm 0.81$ & $14.65 \pm 0.21$ & $14.51 \pm 0.03$ & $14.47 \pm 0.23$ \\
\hline Yolk weight (\%) & $23.63 \pm 1.85$ & $24.85 \pm 0.60$ & $24.80 \pm 0.70$ & $24.47 \pm 0.21$ \\
\hline Yolk color score & $9.00 \pm 0.50^{\mathrm{b}}$ & $10.00 \pm 0.00^{\mathrm{a}}$ & $10.00 \pm 0.00^{\mathrm{a}}$ & $10.00 \pm 0.00^{\mathrm{a}}$ \\
\hline Eggshell weight (g) & $7.30 \pm 0.28$ & $7.13 \pm 0.05$ & $7.29 \pm 0.19$ & $7.36 \pm 0.21$ \\
\hline Eggshell weight (\%) & $12.39 \pm 0.49$ & $11.89 \pm 0.41$ & $12.44 \pm 0.22$ & $12.47 \pm 0.31$ \\
\hline Eggshell thickness (mm) & $0.35 \pm 0.01$ & $0.35 \pm 0.00$ & $0.35 \pm 0.01$ & $0.35 \pm 0.00$ \\
\hline
\end{tabular}

Note: $\mathrm{R} 0=$ diet without supplementation $(0 \%)$ coriander seeds powder, $\mathrm{R} 1=$ diet with supplementation of $1 \%$ coriander seeds powder, $\mathrm{R} 2=$ diet with supplementation of $2 \%$ coriander seeds powder, $\mathrm{R} 3=$ diet with supplementation of $3 \%$ coriander seeds powder. Means in the same row with different superscripts differ significantly $(\mathrm{P}<0.05)$. 
zeaxanthin, lutein, alpha-carotene, beta-carotene and carotenoids.

The treatments did not affect eggshell weight. The average of eggshell weights in this research was higher than reported by Cayan \& Erener (2015) that was $6.63 \mathrm{~g}$ $(11.00 \%)$. According to Yoon et al. (2015), piperine powder will inhibit the activity of $\mathrm{Ca}^{2-} \mathrm{ATP}$-ase enzyme in transporting the calcium ions across the cell membrane that will decrease calcium. Inhibition of calcium absorption results in decreased egg quality, such as egg weight and eggshell strength. Eggshell quality could be influenced by the age and the content of mineral nutrients in the feed, such as calcium, magnesium, and phosphorus as inorganic constituent (Darmawan et al., 2013; Hincke et al., 2011). Furthermore Leeson and Summers (2005) stated that the mineral nutrients that contributed to the thickness and eggshell strength were calcium, magnesium, carbonates, phosphorus, vitamin D3, and other organic nutrients, including protein.

Supplementation of coriander seeds did not affect the eggshell thickness (Table 3). The average of eggshell thickness in this research was different from that reported by Hu et al. (2011) and Park et al. (2015) that was 0.35 $\mathrm{mm}$ and $0.37 \mathrm{~mm}$, respectively. According to Leeson \& Summers (2005), the main nutrients that affect the eggshell thickness are calcium, phosphorus, and vitamin D3. The contents of $\mathrm{Ca}$ and $\mathrm{P}$ in the diet contribute to the quality of the eggshell because carbonate and $\mathrm{Ca}$ ions are required to form $\mathrm{CaCO}_{3}$ in eggshell. According to Kebreab et al. (2009), the higher the calcium intake the higher quality of the eggshell.

\section{CONCLUSION}

Supplementation of coriander seeds at the level of $2 \%-3 \%$ decreased feed intake, feed conversion ratio, and increased yolk color. However supplementation at all levels did not affect egg weight, egg production, and egg mass.

\section{REFERENCES}

Abou-Elkhair R., H. A. Ahmed, \& S. Selim. 2014. Effects of black pepper (piper nigrum), turmeric powder (curcuma longa) and coriander seeds (coriandrum sativum) and their combinations as feed additives on growth performance, carcass traits, some blood parameters and humoral immune response of broiler chickens. Asian-Australas. J. Anim Sci. 27(6):847-854. http://dx.doi.org/10.5713/ajas.2013.13644.

Ahmad, N., H. Fazal, B. H., Abbasi, S. Farooq, M. Ali, M, \& M. A. Khan. 2012. Biological role of Piper nigrum L. (black pepper): A review. Asian. Pac. J. Trop. Biomed. 2(Suppl. 3): 1945-1953. http://dx.doi:10.1016/S2221-1691(12)60524-3.

Al-jaff, F. K. 2011. effect of coriander seeds as diet ingredient on blood parameters of broiler chicks raised under high ambient temperature. Int. J. Poult. Sci. 10:82-66.

AOAC. 2005. Official Methods of Analysis of AOAC International. 18th ed. Assoc. Off. Anal. Chem., Arlington.

Balitro (Balai Penelitian Tanaman Rempah dan Obat). 2015. Sertifikasi Pengujian Biji Ketumbar 15 Januari 2015. Laboratorium Balai Penelitian Tanaman Rempah dan Obat, Bogor.

Begnami, A. F., M. C. T. Duarte, V. Furletti, \& V.L.G. Rehder. 2009. Antimicrobial potential of Coriandrum sativum L. against different Candida species in vitro. J. Food.Chem.118 (2010) 74-77. http://dx.doi:10.1016/j.foodchem.2009.04.089.

Bhat, S., P. Kaushal1, M. Kaur2 \& H. K. Sharma. 2014. Coriander (Coriandrum sativum L.): Processing, nutritional and functional aspects. Afr. J. Plant Sci. 8:25-33. http://dx.doi: 10.5897/ajps2013.1118.

Bidura, I G., N. G., E. Puspani, D. A. Warmadewi, T. G. O. Susila, \& I. W. Sudiastra. 2014. Pengaruh penggunaan pollard terfermentasi dengan ragi tape dalam ransum terhadap produksi telur ayam Lohmann Brown. Majalah Ilmiah Peternakan 17(1).

BPS. 2015. Produksi dan populasi ternak. http://www.bps. go.id/index.php.[29 April 2015].

Brenes \& E. Roura. 2010. Essential oils in poultry nutrition: main effects and modes of action. J. Anim. Feed Sci. Technol. 158: 1-14. http://dx.doi:10.1016/j.anifeedsci.2010.03.007.

Burdock, G. A., G. Loana, \& Carabin. 2008. Safety assessment of Coriander (Coriandrum sativum L.) essensial oil ingredient. Food Chem. Toxicol. 47. 22-34. http://dx.doi:10.1016/j. fct.2008.11.006.

Cayan, H., \& G. Erener. 2015. Effect of olive leaf (Olea europaea) powder on laying hens performance, egg quality and egg yolk cholesterol levels. Asian Australas. J. Anim. Sci. 28:538-543. http://dx.doi:10.5713/ajas.14.0369.

Christaki, E, Eleftherios Bonos, Ilias Giannenas \& Panagiota Florou-Paneri. 2012. Aromatic Plants as a Source of Bioactive Compounds. J. Agriculture 2:228-243. http:// dx.doi:10.3390/agriculture2030228.

Christaki, E., E. Bonos, \& P. Florou-Paneri. 2011. Effect of dietary supplementation of olive leaves and/or tocopheryl acetate on performance and egg quality of laying Japanese quail (Coturnix japonica). Asian J. Anim. Vet. Adv. 6:12411248.

Darmawan, A., K. G. Wiryawan, \& Sumiati. 2013. Egg production and quality of magelang duck fed diets containing different ratio of omega 3 : omega 6 and organic Zn. Med. Pet. 36: 197-202. http://dx.doi: 10.5398/medpet.2013.36.3.197.

Guler, T., O. N. Ertas, M. Ciftci, \& B. Dalkhe. 2005. The effect of coriander seed (Coriandrum sativum L.) as diet ingredient on the performance of Japanese quail. J. Anim. Sci. 35: 260-266.

Hammershoj, M., U. Kidmose, \& S. Steenfeldt. 2010. Deposition of carotenoids in egg yolk by short-term supplement of coloured carrot (Daucus carota) varieties as forage material for egg-laying hens. J. Sci. Food. Agric. 90:1163-1171. http://dx.doi: 10.1002/jsfa.3937.

Han, Yung-Keun \& P. A. Thacker. 2011. Influence of energy level and glycine supplementation on performance, nutrient digestibility and egg quality in laying hens. AsianAust. J. Anim. Sci. 24: 1447-1455. http://dx.doi:/10.5713/ ajas.2011.11123.

Hermana, W., T. Toharmat, Sumiati, \& W. Manalu. 2014. Performances and egg quality of quail offered feed containing sterol from katuk (Sauropus androgynus) and mulberry (morus alba) leaf meal. Int. J. Poult. Sci. 13:168-172. http:// dx.doi: 10.3923/ijps.2014.168.172.

Hincke, M., J. Gautron, A. B. Rodriguez-Navarro, \& M. D. McKee. 2011. The Eggshell: Structure and Protective Function. In: Y. Nys, M. Bain \& F. V. Immerseel (Eds.). Improving the Safety and Quality of Eggs and Egg Products. Woodhead Publishing, United Kingdom. p. 151-182.

Honkatukia, M., Tuiskula-Haavisto, M. Arango, J. Tabell, J. Schmutz, M. R. Preisinger, \& J. Vilkki. 2013. QTL mapping of egg albumen quality in egg layers. J. Genetics, Selection, Evolution : GSE, 45: 31-31.

Hosseinzadeh, H., Ali Ahmad Alaw Qotbi, Alireza Seidavi, David Norris, \& David Brown. 2014. Effects of different levels of coriander (Coriandrum sativum) seed powder and extract on serum biochemical parameters, microbiota, and 
immunity in broiler chicks. The Scientific World Journal. 11:628-979. http://dx.doi.org/10.1155/2014/628979.

Hu, C.H., A.Y. Zuo, D.G. Wang, H.Y. Pan, W.B. Zheng, Z.C Qian, \& X. T. Zou. 2011. Effects of broccoli stems and leaves meal on production performance and egg quality of laying hens. J. Anim. Feed Sci. Technol. 170:117-121. doi:10.1016/j.anifeedsci.2011.07.019

Kebreab, E., J. France, R. P. Kwakkel, S. Leeson, H. D. Kuhi, \& J. Dijkstra. 2009. Development and evaluation of a dynamic model of calcium and phosphorus flows in layer. Poult Sci. 88:680-68. http://dx.doi.org/10.3382/ps.200800157.

Khani \& Tahere Rahdani. 2012. Chemical composition and insecticidal activity of essential oil from Coriandrum sativum seeds against Tribolium confusum and Callosobruchus maculatus. International Scholarly Research Network ISRN Pharmaceutics 2012:1-5.

Kim, J., S. M. Seo, S. G. Lee, S. C. Shin, \& I. K. Park. 2008.“Nematicidal activity of plant essential oils and components from coriander (Coriandrum sativum), oriental sweetgum (Liquidambar orientalis), and valerian (Valeriana wallichii) essential oils against pine wood nematode (Bursaphelenchus xylophilus)," J. Agr. Food Chem. 56: 7316-7320.

Lesson, S \& J. Summers . 2005. Commercial Poultry Nutrition. $3^{\text {rd }}$ Ed. Departement of Animal and Poultry Science, University Guelp.University Books, Canada (CA).

Lee, S. H., H. S. Lillehoj, S. I. Jang, E. P. Lillehoj, W. Min, \& D. Bravo. 2013. Dietary supplementation of young broiler chickens with capsicum and turmeric oleoresins increases resistance to necrotic enteritis. Br. J. Nutr. 110:840-847.

Loetscher, Y., M. Kreuzer, R. E. Messikommer. 2013. Utility of nettle (Urtica dioica) in layer diets as a natural yellow colorant for egg yolk. J. Anim. Feed Sci. Technol. 186: 158-168.

Mahmoud, K. Z., M. Saad, Gharaibeh, A. Hana, Zakaria, \& A. M. Qatramiz. 2010. Garlic (Allium sativum) supplementation: influence on egg production, quality, and yolk cholesterol level in layer hens. Asian-Australas. J. Anim. Sci. 23: 1503-1509.

Matasyoh, J. C., Z. C Maiyo, \& R. M. Ngure. 2008. Chemical composition and antimicrobial activity of the essential oil of Coriandrum sativum. J. Food Chem. 113: 526-529.

Mattjik, A. A. \& I. M. Sumertajaya. 2006. Perancangan Percobaan. IPB Press, Bogor.

Nugraha, B. A., K. Widayaka, \& N. Iriyanti. 2013. Penggunaan berbagai jenis probiotik dalam ransum terhadap haugh unit dan volume telur ayam Arab. Jurnal Ilmiah Peternakan 2:606-612.

Olobatoke R. Y. \& S. D. Mulugeta. 2011. Effect of dietary garlic powder on layer performance, fecal bacterial load, and egg quality. Poult. Sci. 90 :665-670 http://dx.doi: 10.3382/ ps.2010-00736.
Park, J. H., S. D. Upadhaya, \& I. H. Kim. 2015. Effect of dietary marine microalgae (Schizochytrium) powder on egg production, blood lipid profiles, egg quality, and fatty acid composition of egg yolk in layers. Asian Australas. J. Anim. Sci. 28: 391-397.

Rajeshwari \& B. Andallu. 2011. Medicinal benefits of coriander (Coriandrum sativum L). Spatula DD 1: 51-58.

Rajkumar, U., R. P. Sharma, K. S. Rajaravinda, \& M. Niranjan. 2009. Effect of genotype and age on egg quality traits in naked neck chicken under tropical climate from india. Int. J. Poult. Sci. 8:1151-1155. http://dx.doi:10.3923/ ijps.2009.1151.1155.

Silva, F., S. Ferreira, J. A. Queiroz, \& F. C. Domingues. 2011. Coriander (Coriandrum sativum L.) essential oil: its antibacterialactivity and mode of action evaluated by flow cytometry. J. Med Microbiol. doi: 10.1099/jmm.0.034157-0. (Abstr).

Stadelman, W. J. \& O. J. Cotterill. 1995. Egg Science and Technology. 4th ed. Food Products Press, New York, London.

Subekti, S., W. G. Piliang., W. Manalu, \& T. B. Murdiati. 2006. Penggunaan tepung daun katuk dan ekstrak daun katuk (Sauropus androgynus L.Merr) sebagai substitusi ransum yang dapat menghasilkan produk puyuh jepang rendah kolesterol. JITV 11: 254-259.

Tserveni-Goussi, A., \& P. Fortomaris. 2011. Production and Quality of Quail, Pheasant, Goose and Turkey Eggs for Uses Other than Human Consumption. In: Y. Nys, M. Bain \& F. V. Immerseel (Eds.). Improving the Safety and Quality of Eggs and Egg Products. Woodhead Publishing, United Kingdom. p. 509-537.

Tuleun, C., \& A. Adenkola. 2013. Performance and erythrocyte osmotic membrane stability of laying japanese quails (coturnix coturnix japanica) fed varying dietary protein levels in a hot-humid tropics. J. Agric. Biol. Am. 4:6-13. http:// dx.doi: 10.5251/abjna.2013.4.1.6.13.

Windisch, W., K. Schedle, C. Plitzner, \& A. Kroismayr. 2008. Use of phytogenic products as feed additives for swine and poultry. J. Anim .Sci. 86: E140-148.

Yoon, Y. C., S. H. Kim, M. J. Kim, H. J. Yang, M. R. Rhyu, \& J. H. Park. 2015. Piperine, a component of black pepper, decreases eugenol-induced cAMP and calcium levels in non-chemosensory 3T3-L1 cells. Febs. Open. Bio. 5:20-25. http://dx.doi: 10.1016/j.fob.2014.11.008.

Zangeneh, S. \& M. Torki. 2011. Effects of $b$-mannanase supplementing of olive pulp included diet on performance of laying hens, egg quality characteristics, humoral and cellular immune response and blood parameters. Global Vet. 7:391-398. 